Louisiana State University

LSU Digital Commons

\title{
'People are enemies to what they don't know' managing stigma and anti-Muslim stereotypes in a Turkish Community Center
}

\author{
Crystal Paul \\ Louisiana State University and Agricultural and Mechanical College, cpaul6@lsu.edu \\ Sarah Anna Becker \\ Louisiana State University and Agricultural and Mechanical College, sbecker@lsu.edu
}

Follow this and additional works at: https://digitalcommons.Isu.edu/sociology_pubs

Part of the Ethnic Studies Commons, Inequality and Stratification Commons, Islamic Studies

Commons, Race and Ethnicity Commons, Sociology of Culture Commons, and the Sociology of Religion

Commons

\section{Recommended Citation}

Paul, C., \& Becker, S. A. (2017). 'People are enemies to what they don't know' managing stigma and antiMuslim stereotypes in a Turkish Community Center. Journal of Contemporary Ethnography,, 46 (2), 135-172. https://doi.org/10.1177/0891241615570053

This Article is brought to you for free and open access by the Department of Sociology at LSU Digital Commons. It has been accepted for inclusion in Faculty Publications by an authorized administrator of LSU Digital Commons.

For more information, please contact ir@lsu.edu. 


\section{"People Are Enemies to What They Don't Know" Managing Stigma and Anti-Muslim Stereotypes in a Turkish Community Center}

Journal of Contemporary Ethnography 2017, Vol. 46(2) I35-172

(C) The Author(s) 2015

Reprints and permissions: sagepub.com/journalsPermissions.nav DOI: $10.1177 / 0891241615570053$ journals.sagepub.com/home/jce

@SAGE

\title{
Crystal Paul' and Sarah Becker'
}

\begin{abstract}
In the wake of the $9 / 1$ I terrorist attacks on the World Trade Center, antiMuslim discourse and sentiment has become pervasive in the West. Using a collaborative ethnographic approach, we observe how participants at a Turkish Community Center (TCC) cultivate stigma management strategies against the cultural backdrop of post-9/II anti-Muslim stereotypes. In our analysis, we use Goffman's work on stigma and critical race theory to explore the socially embedded nature of stigmatization processes for Turkish Muslims in a local community center. Our findings reveal how aspects of Turkish culture and Islam, together with a structural context that facilitates collective stigma management, allow TCC participants to effectively manage stigma and combat anti-Muslim stereotypes. Turkish participants use the practice of "dialogue" to prioritize secular identity(ies) through cultural education, normalize the Muslim self in conversation about religion, and embody a gendered presentation of Islam and Turkish culture. While facilitating individual and collective resilience for TCC participants in the face of stigmatization and pervasive anti-Muslim sentiment, these practices also contribute to the reproduction of broader patterns of racial, cultural, and gender inequality.
\end{abstract}

'Louisiana State University, Baton Rouge, LA, USA

\section{Corresponding Author:}

Crystal Paul, MA, Sociology Department, Louisiana State University, 126 Stubbs Hall, Baton Rouge, LA 70803

Email: cpaul6@Isu.edu 


\section{Keywords}

stigma management, Islam, cultural education, dialogue, critical race theory

\section{Introduction}

Muslims have long been subject to orientalist discourse, which negatively stereotypes them as violent, militaristic, uncivilized, and fanatical (Said 1979; Saloom 2005). However, fueled by the 9/11 attacks on the World Trade Center and propelled by public acts of violence committed by individuals touting Islamic fundamentalist ideologies, Islamophobia and anti-Muslim stereotypes have reached unprecedented levels in recent years (Johns, Schmader, and Lickel 2005; Klandermans, van der Toorn, and van Stekelenburg 2008; Panagopoulos 2006; Sirin and Balsano 2007). Muslims, particularly those in the United States, therefore experience especially intense stigmatization in the modern context (Ayoub 2011; el-Aswad 2013).

Studies illustrating how Muslim Americans manage stigma post-9/11 are part of a growing body of scholarship on stigmatization processes that examines how people experience, resist, challenge, and transform stigma (Marvasti 2005; Mir 2011; Umbreit, Lewis, and Burns 2003). Through this research, scholars have identified a range of strategies that provide selfprotective benefits to Muslim individuals and that illustrate Muslims' considerable resilience in the face of negative stereotyping and discriminatory treatment (Küçükcan 2004; O’Brien 2011; Ryan 2011; Valenta 2009). In addition, scholars have recently pushed for examinations of power that will highlight the broader structural forces and historical events that help explain how stigma works: where it emerges, how people manage it, and what its consequences are (Barreto and Ellemers 2010; Link and Phelan 2001).

In this analysis, we build on scholarship documenting how people collectively experience and resist stigma while also taking seriously the challenge of interrogating power dynamics in stigmatization processes. Using a collaborative ethnographic approach and a critical theoretical lens, we examine how local Turkish Community Center (TCC) participants attempt to manage stigmatized identities and dispel Islamophobic stereotypes. We explore how they recognize their stigmatized status and seek to reinvent the Muslim identity in the minds of non-Muslim Americans by complicating what being Muslim means. Our findings illustrate how Turks at the TCC employ the practice of "dialogue" to emphasize nationality over religion in their cultural education efforts, to normalize the Muslim self, and to embody Islamic ideals through gendered presentations of Turkishness. These practices allow them to effectively manage stigma, but have broader consequences for racial, ethnic, cultural, and gender inequality in the United States. 


\section{Islamophobia and Negative Muslim Stereotypes Post-9/I I}

"I have not been able to discover any period in European or American history since the Middle Ages in which Islam was generally discussed or thought about outside a framework created by passion, prejudice, and political interests."

-Edward W. Said (1980, p. 488)

Negative views of Middle Eastern people and of Islam have long been embedded in Western popular belief systems and scholarship (Allison 2013; el-Aswad 2013; Said 1979). Indeed, Westerners have traditionally viewed Muslim people(s) through an Orientalist lens that portrays them as an object of fear, hostility, and/or exoticization. However, 9/11 galvanized a shift in the intensity and character of Westerners' perceptions of the Islamic "other" (Alam 2006; Tuastad 2003). Islamophobia, or the "unfounded hostility towards Islam, and therefore fear or dislike of all or most Muslims" (Runneymede Trust 1997), has become so pervasive in the United States that in 2006 American Muslims elicited more negative views than any other religious minority group in the United States (Kalkan, Layman, and Uslaner 2009). In 2009, a Gallup poll revealed that Americans are twice as likely to maintain negative feelings toward Muslims as they are toward individuals of any other major religion (Gallup, Inc. 2009). Anti-Muslim sentiment, catalyzed by the events of 9/11, may also be exacerbated by Islam's position as the fastest growing religion in the United States today (Ayers 2007). Scholars have documented how many non-Muslim Americans are not only threatened by the negative images presented to them in the media (Ali et al. 2011), especially post-9/11, but also by the increasing prevalence of a formerly unfamiliar religion (Ayoub 2011).

Under these conditions, an unparalleled number of anti-Muslim hate crimes and targeted acts of violence cropped up in communities throughout the United States after 9/11 (Ayers 2007). In fact, the number of anti-Muslim hate crimes reported the year following $9 / 11$ exceeded those reported by black, Jewish, and gay individuals; while the reports leveled off in 2002, Muslims continue to claim remarkably high levels of hate crime victimization (Rubenstein 2004). According to Ayers's (2007) estimates, 57 percent of American Muslims reported personally experiencing bias or discrimination themselves and 87 percent reported knowing a fellow Muslim who had experienced verbal abuse, discrimination in the workplace, and/or religious profiling. Perhaps even more telling about the post-9/11 Muslim experience in the United States is the fact that 40 percent of American Muslims believe that "the U.S. is fighting a war against Islam" (Ayers 2007). Illustrative of this 
figurative war, researchers have demonstrated how the personal experiences of individuals who look Middle Eastern reveal how Americans are effectively pitted against them irrespective of their actual faith (Brennan 2011). In addition to coping with violence and strained social interactions, Muslim immigrants/individuals exhibiting a Middle Eastern appearance have also been subject to increasingly restrictive legal regulations (Klandermans, van der Toorn, and van Stekelenburg 2008; Patel 2012), especially pertaining to state, national, and international securitization measures taken by the United States government (Bleich 2009).

\section{Stigma and Stigmatization Processes}

Social scientists have most frequently used the concept of stigma to situate the experiences of individuals, like Muslims, who are identified by negatively connoted statuses such as race (Howarth 2006; Storrs 1999), religion (Ryan 2011), sexuality (Herek 1998; Herek, Saha, and Burack 2013), and health (Fink and Tasman 1992; Parker and Aggleton 2003; Scambler 2009). A large body of research demonstrates that a stigmatized status "contaminates" people's identities and has implications for the stigmatized individual's life chances, particularly in relation to suffering, social isolation, health, and wellness (Carr and Friedman 2005). This is especially true for those whose stigmatized status is highly visible, such as those whose bodies carry markers of stigmatized racial (Fernández 2007; Lenhardt 2004) or health (Kleck 1968; Puhl and Brownell 2006) status or those who wear highly recognizable and easily identifiable religious clothing (Endelstein and Ryan 2013; Ghumman and Jackson 2010).

Though scholars often approach stigma development and its consequences in relation to individual social status positions such as race, class, gender, able-bodiedness, and religion, stigmatization is a socially embedded process (Collins 2004; Corrigan and Watson 2002). As such, a growing body of research addresses how stigmatized group members experience, resist, and challenge stigma. For example, microlevel factors such as the "specific norms and expectations" that structure intergroup relationships and govern cross-group contact affect how, when, and where members of stigmatized groups experience discrimination (Barreto and Ellemers 2010, p. 435). Similarly, the presence of community and religious organizations influences how stigmatized group members can positively cope with unfair treatment (Abdullah 2009; Göle 2003). Access to groups that reject negative stereotypes, resist stigmatization, and provide social support also provides important self-protective benefits to individuals managing stigma (Küçükcan 2004; O'Brien 2011; Ryan 2011; Valenta 2009). 
Scholars have identified a host of collective and individual responses to post-9/11 anti-Muslim sentiment that illustrate group resilience. For example, studies recognize the benefits of seeking the help of others or adopting positive religious strategies when confronted with anti-Muslim behavior or media portrayals (Abu-Raiya, Pargament, and Mahoney 2011; Barkdull et al. 2011; Bonet 2011; Umbreit, Lewis, and Burns 2003). Some Muslims have embraced a self-preservation approach, attempting to distance themselves from the negative and violent images associated with Islam and identify, instead, with the Muslim rhetoric of peace and tolerance, despite the intensified anti-Muslim sentiment directed toward them (Ayoub 2011; el-Aswad 2013; I. Kaya 2004). Indeed, many Muslim groups have expressed the sorrow and compassion they feel toward the victims and the victim's families of terrorist attacks related to Islamic fundamentalism and have internalized a sense of shame and embarrassment to be associated with individuals who would cause such devastation (Johns, Schmader, and Lickel 2005; Khalid 2007).

Additionally, some Muslims engage in group-based activities that aid in the management of anti-Muslim stereotypes (I. Kaya 2004; Umbreit, Lewis, and Burns 2003). Embarking upon educational campaigns (O'Brien 2011), partnering with non-Muslim religious organizations, and intentionally sparking interfaith dialogue are among the range of resilient group responses that act to buffer Muslims against the negative impacts of stigmatization (Barkdull et al. 2011; Khalid 2007). Some Muslims, for example, have reached out to hate crime victims and offenders in the hopes of finding or encouraging emotional support and healing and promoting cultural education aimed at reducing hate crime recidivism (Abu-Raiya, Pargament, and Mahoney 2011; Barkdull et al. 2011; Umbreit, Lewis, and Burns 2003). Others, however, prefer to seek respite through intragroup relations. Although it may cause additional hardships for Muslims, because their assumed failure to assimilate to western non-Muslim culture may be interpreted as lack of loyalty to their host country, many turn toward a stronger identification with their Muslim culture as a shield against anti-Muslim sentiment (Barkdull et al. 2011; Klandermans, van der Toorn, and van Stekelenburg 2008).

\section{Stigma and Social Structure}

Studies like these, which examine stigmatization and stigma management as socially embedded processes, involve identifying immediate contextual factors - such as the availability of resources to launch a campaign or the presence of a local Muslim community to work alongside - that fuel specific stigma management techniques. They also look at the social 
structural factors-like hegemonic values, prevailing social norms, and broader patterns of inequality - that influence stigma development and management (Goffman 1963). Scholars have recently offered a more tightly sculpted and reinvented definition of stigma that emphasizes looking more closely at social structure and relations of power (Link and Phelan 2001). Here, "stigma exists when the elements of labeling, stereotyping, separating, status loss and discrimination co-occur in a power situation that allows these processes to unfold" (Link and Phelan 2001, p. 382). Studies that examine these "power situations" reveal how macrolevel structural factors such as economic trends and societal change influence discrimination against stigmatized groups (Barreto and Ellemers 2010; Collins 2004; Corrigan and Watson 2002; Scambler 2009).

Critical race theory, with a long tradition of interrogating power, fits well with this approach. Building on classic works that examine how macrolevel racial inequalities manifest at the micro level (Du Bois 1903; Fanon 1967), critical race theorists regularly explore the impact social structure has on the daily experiences of racialized others. Many of these analyses explore how inequality is embedded in and perpetuated by seemingly neutral language, practices, and institutions (Crenshaw 1991; Duster 2003; Feagin 2013). Recent works, especially, have analyzed how language that seems to stress equality, tolerance, or celebration of diversity nonetheless contributes to the reproduction of racism and inequality (Bonilla-Silva 2010; Crenshaw 2011; Hage 1998). For example, Hage (1998) illustrates how white multiculturalism "works to mystify, and to keep out of the public discourse, other multicultural realities" (p. 19). Though multiculturalist rhetoric emphasizes tolerance and celebration of diversity, white people largely retain power to produce images of themselves and ethnic/racial "others" that frame some people as safe and others as potentially dangerous outsiders.

Crenshaw (2011) documents a similar trend in President Obama's "racial maneuvering" on the campaign trail. She argues that him referring to Jeremiah Wright's anger over racial inequality as "powerful" and "misunderstood" frames Wright/his followers and their white critics as equal, "warring factions whose pain was both legitimate and misunderstood by the other" (Crenshaw 2011, p. 1322). By acknowledging the legacy of race in America, but framing it as something we all must move past, Obama's "dissociative gesture" appeases potential voters while leaving intact "the racial barriers that continue to shape the life chances of many people of color" (Crenshaw 2011, p. 1333). Other critical race feminist scholars illustrate how transnational feminist activists risk participating in the same dynamic. Adopting a "paternalistic" approach to Arab women that frames them as in need of rescue from oppressive Arab men/regimes, views them through a "lens of 
inferiority," or imposes Western value systems on them and perpetuates stereotypes of Arab women as powerless and passive (Saloom 2005, p. 73-74).

As these studies suggest, critical race theorists document how seemingly progressive moves like multiculturalism, frank discussion of racism, or transnational feminist activism, because they take place amidst unbalanced power relations, tend to reproduce rather than challenge inequality. In this context, racialized/ethnic others who occupy a position of limited power to challenge dominant discourse are left to navigate negative and/or "whitecentered" images of themselves in day-to-day interaction (Chou and Feagin 2008; Hage 1998). The strategies they use to undertake this navigation both stem from and independently challenge or reinforce preexisting patterns of structural inequality.

For Muslims in the United States, longstanding patterns of negative stereotyping by Westerners are one factor that illustrates how imbalanced socialstructural power dynamics influence stigmatization processes. Muslim people, customs, practices, and traditions have historically been "othered" in orientalist discourse (Said 1979; Saito 2001). After 9/11, the trend intensified as people reimagined Islam as a clear and ever-present threat, putting "immense pressure on [Muslim] communities to negotiate the sustained moral and social stigmatization in narrating Islam" (Ibrahim 2007, p. 47). Muslims became "intolerable subjects" who face pressure to display loyalty, adopt Western values, and "prove the legitimacy of their belonging" (Lentin and Titley 2012, p. 123). This, together with general cultural insecurities associated with the shift to a neoliberal state (Garland 2001; Wacquant 2010) and the widespread belief that we live in a postracial society (Bonilla-Silva 2010; Crenshaw 2011) make it likely that Muslim Americans' stigma management techniques - like those of most marginalized groups embedded in social structures with unequal power dynamics - will emphasize integration and therefore contribute to the reproduction of inequality (Lentin and Titley 2012).

In this paper, we use collaborative ethnographic methods to address that question. We examine how members of a local Turkish community center manage and challenge stigma in an institutional context that encourages intra- (i.e. Turkish Muslim) and intergroup (i.e. non-Muslim American) interactions. Drawing on critical race theory (Crenshaw 2011; Lentin and Titley 2011; Saloom 2005), we contribute to stigma scholarship by examining the socially embedded nature of stigmatization processes and the "power situations" in which they unfold (Link and Phelan 2001). Our findings reveal that Turkish participants manage stigma through three discursive and embodied "dialogue" strategies: emphasizing secular identity/ies by focusing on cultural education, normalizing the Muslim self in conversation about religion, 
and presenting their ideals through the gendered self. These strategies stem from and have consequences for structural inequality in the United States.

\section{The Turkish Community Center (TCC)}

The Turkish Community Center (TCC) ${ }^{1}$ is a cultural organization in a midsized southern city that attempts to encourage and facilitate intercultural/ interfaith dialogue. It is a branch of a larger regional organization founded by Turkish volunteers for the now international Hizmet (service) or Gülen Movement. These Turks follow the teachings of Fethullah Gülen, ${ }^{2}$ a Muslim Turk currently residing in the United States who promotes Islam as a peaceful and tolerant religion and preaches that education and altruism should be paramount among its followers (Ebaugh 2010; Gülen 2004). Funded by an estimated 20 million supporters worldwide, who are reported to donate between 5 to 20 percent of their yearly income to the cause, the Gülen movement is responsible for establishing Islam-driven schools, media outlets, and cultural centers, like the TCC, across the globe (BBC World News 2013; Ebaugh 2010). The Gülen movement does not have any official membership but is instead comprised of an informal, invisible network of advocates located around the world (BBC World News 2013). The majority of members, however, continue to reside in Turkey, and it is speculated that many Gülen followers hold influential positions at all levels of the Turkish government; opponents of Gülen believe that he is encouraging his Turkish followers to infiltrate the Turkish government in order to one day dismantle the Turkish secular state (Arango 2013; BBC World News 2013). Despite these accusations, members of the Gülen movement, including those at the TCC, continue to focus their efforts on intercultural/interfaith dialogue at a local level hoping to contribute to the larger, international Hizmet movement.

According to their informational literature, the stated purpose of the TCC's many organized activities such as luncheons, dinners, and spiritual meetings is to foster communication between individuals of diverse backgrounds, aid in relationship building, and promote cross-cultural education. These cultural education efforts are uniformly practiced by groups who support Gülen, not with the intention of recruiting individuals into the movement but to encourage intercultural/interfaith dialogue (Ebaugh 2010). Like other groups affiliated with the Gülen movement, the TCC has three main types of events: (1) annual/semiannual large-scale events that formally highlight the center and its mission to the public, the media, and/or local spiritual leaders; (2) Smallerscale weekly, monthly, or quarterly informal events designed to highlight Turkish culture, but also to occasionally discuss American culture or history; (3) Turk-only events. The majority of these activities — book club meetings, 
cooking classes, luncheons, children's activities, and cultural gatherings, for example - are held at its headquarters located on a main road at the edge of a residential neighborhood. Large events such as cultural festivals, diversity conferences, or the Annual Dialogue Dinner are held elsewhere. The TCC building has a children's playroom, reading room, prayer room, large kitchen (necessary for the preparation of food, which is home-cooked for nearly all TCC events), and a spacious living/dining space.

The TCC's annual large-scale events and regular, smaller-scale classes, gatherings, and activities are indicative of their mission to educate Americans about both Muslim and Turkish culture and to stimulate dialogue. Events reserved for Turks only suggest that Turkish TCC participants are not interested in complete acculturation. Instead, they focus on successful integration while remaining committed to their own cultural values. Therefore, they hold religious celebrations, Turkish language classes for children, and even social activities for Turks at the TCC building. Turk-only events are not prohibitive, however. If an American wants to attend, they can (and some, like Crystal, did) but the program is presented in Turkish and the events are not advertised for outside of the TCC Turkish community. Public events, on the other hand, are advertised on the TCC website, via email, or on flyers distributed in the local community. Nonetheless, these events usually draw participants who have a personal tie with a TCC member.

The TCC is located in an economically thriving midsized southern city. Due in part to the presence of several universities and colleges, the city maintains a Democratic majority and has a relatively high number of foreign-born residents compared with the surrounding area. Only 1 percent of the city's recorded religious practitioners are Muslim (Pew Research Center 2014). The majority of people are either evangelical Protestants or Catholic (Pew Research Center 2014). Most of the city's residents are white (40 percent) or black (55 percent) (United States Census 2010). People of other racial/ethnic backgrounds make up only a small fraction of the population. As is the trend with groups associated with Gülen, the TCC has no official procedure for city residents to become members. Instead, informal membership of frequent event attendees and volunteers is implied. In our time in the field, we met a small group of (implied) members: approximately 22 core volunteers who ran and staffed nearly every event and 47 semiactive or very active participants who attended/volunteered at events more frequently than others.

When compared with the city's population, TCC members are disproportionately Turkish Muslims. Almost two-thirds (64 percent) of core volunteers and half of active participants are Turkish Muslims. Turkish/Muslim women are the majority of core volunteers $\left(41\right.$ percent $\left.^{3}\right)$ and 23 percent of active participants. Non-Muslim American women account for 23 percent of core 
volunteers and the majority (43 percent) of active participants. Turkish/ Muslim men are about a quarter of core volunteers and active participants (23 percent). ${ }^{4}$ Non-Muslim American men are 14 percent of core volunteers and 11 percent of active participants. The overwhelming majority of non-Muslim American members are white, middle/upper-middle class retired professionals or students. Though there is a bit more variance among Turkish Muslims (e.g., more families, working professionals, and/or women with limited English skills and less educational achievement), most of them are also middle/uppermiddle class. People who are not members, but who attend TCC events sporadically, are also mostly white American or Turkish ${ }^{5}$ middle/upper-middle class women. Black city residents rarely attend TCC gatherings, but those who do also come from middle/upper-middle class social class backgrounds.

A Board of Directors (BOD) and Executive Administrator oversee the TCC and are responsible for its decision making, finances, and large-scale annual events such as the Annual Dialogue dinner and TCC-sponsored trips to Turkey. Although the individuals on the BOD changed during our data collection period, its demographic characteristics remained unaltered. It consists of two Turkish men (one serving as president), two white American men, and one white American woman. All five are working or retired professionals and considerable financial contributors to the TCC. The Executive Administrator (the only paid position in the organization) is a Turkish Muslim man. The gender and ethnic composition of the TCC's administration reflects broader patterns in inequality, but is also indicative of the organization's goals. For example, putting Americans on the BOD helps Turks accumulate the social and cultural capital required to navigate American culture (Nee and Sanders 2001) and is tied to upper class white American Southerners' tradition of social philanthropy (Kendall 2002). It also reflects the organization's goal of encouraging intercultural dialogue. The TCC administrations' gender composition is related to the fact that most participants adhere to traditional Muslim gender roles that relegate women and men to the private and public spheres, respectively (Güler 2006). An exception is made for Alice, the white American woman on the board of directors who, like many American women at TCC, is not held to the same gender norms that Turkish Muslim women are.

The TCC is a 501(c)(3) nonprofit organization. While fees for various events are suggested, they are rarely solicited. In line with other groups associated with the Gülen movement, the majority of funding for TCC events, the Executive Administrator's stipend, and building costs are donated by Turkish community members. Some of the major donors sit on the BOD, but most of the Turks who sustain the TCC financially are working to support their families (often on one income) or are single students at local universities. In addition to direct fiscal donations provided by Turks, Turkish women regularly 
provide incidentals such as food (essential to every TCC event, no matter how small in size), silverware, or themed decorations. Contributions from Turkish members are only occasionally supplemented by donations from Americans who attend events.

\section{Methodology}

Data for this analysis come from a two-year collaborative ethnography at TCC. Crystal, an American woman, collaborated with Eyup, a Turkish male graduate research assistant, to collect data for this study. Crystal gained access to TCC through Yilmaz, a Turkish acquaintance of Eyup's who was the Executive Administrator of TCC at the time. Yilmaz invited both researchers to various engagements at the TCC. Once established as participants, we solicited TCC event attendees for interviews. While collaborative ethnographies in the anthropological tradition involve researchers and participants working together at all stages in the research process (Lassiter 2005; Rappaport 2008), we employed a sociological collaborative ethnographic approach. Here, the researchers, not researchers and participants, work collaboratively throughout the process (May and Patillo-McCoy 2000). This collaborative approach was advantageous in that throughout all phases of our research, we were able to explore multiple interpretations of the data and utilize the divergence of our individual attributes (gender, ethnicity, language skills, theoretical orientation/methodological strengths) to gain insight that would otherwise not have been apparent or available.

We coordinated our fieldwork efforts by simultaneously collecting data from a single setting as often as possible (May and Patillo-McCoy 2000). To ensure an ample amount of data collection, both researchers attended a variety of TCC gatherings including cultural events such as cooking classes and coffee nights, informational luncheons featuring speakers from the community, book club meetings, religious celebrations, the Annual Dialogue Dinner, a community fundraiser and a large cultural festival. On occasion, restrictions such as the gender composition of event participants (e.g. women's cooking classes) or language barriers (e.g. interviewees who did not speak English) prohibited both researchers from attending particular events. Therefore, the eligible researcher (e.g. Crystal for the women's cooking classes) attended and collected data. When these restraints arose, the person who attended the event would immediately share field notes, recorded conversations and other data for coding and analysis. Some TCC events-like family picnic days or Turkish language/cultural classes for children-were for Turkish participants only. Our analysis is limited to events where the general public was openly invited. 
We spent a combined total of approximately 100 hours in the field. Identifying ourselves as researchers allowed us to take notes in the field (on a small notepad during the event) with little disruption-notes we subsequently used to compose a complete account of the event for coding and analysis. Whether we took in-field notations (and how detailed/lengthy they were) depended upon the event attended. For example, during luncheons and cooking classes, note taking was common. Many participants wrote down questions to ask the speaker or made notations about recipe ingredients. We were therefore able to take notes openly and with little restriction. However, during coffee night or at religious celebrations, open and lengthy note taking was difficult and occasionally off-putting for participants, so we refrained from taking in-field notes.

In addition to fieldwork, we conducted a total of seventeen 60-90 minute formally structured interviews with a variety of TCC participants: six American women, one Canadian woman, four Turkish women, two American men, and four Turkish men. We digitally recorded interviews, transcribed them verbatim, and translated from Turkish to English when necessary. Interviews focused on participants' roles in and relationships with the TCC and other TCC participants, their understanding of TCC's mission, and views of its success at mission implementation. Our limited number of interviews is the result of data saturation (observational and interviewee response repetition) and key participants signaling decreased willingness to be interviewed by us. After noticing reduced correspondence, invitations to events, and frequent rescheduling of pending interviews by key informants, Eyup received a phone call from a male Turkish leader at TCC asking why we were questioning participants about gender segregation at events and the gendered division of labor. Noting their discomfort and in order to preserve relationships with respondents and prevent harm in the field (Esterberg 2002), we chose to stop interviewing, but remained in the field as participant-observers. We supplemented formal interviews and observational data with several semistructured informal, often spontaneous, interviews conducted in the field and with textual data and content analysis from the TCC website, brochures, informational literature, PowerPoint presentations, news articles, press releases, and mass e-mails (Esterberg 2002).

Data analysis for the project took place in four stages. First, we compiled interview transcriptions, field notes, and textual data into one dataset. In the second stage, we used an open coding strategy to independently code data line by line (Charmaz 2006; Esterberg 2002). During the open coding process, we also utilized in vivo coding, taking terms directly from participants' commentary to describe particular phenomenon occurring in the field (Charmaz 2006). After we had read and coded each item, we moved into the 
third stage of analysis, which involved auditing codes, determining main themes, and developing our analysis based upon their interconnectedness. Both researchers also composed situational maps, social world maps, and theoretical free writes and memos to aid analysis and enhance thematic composition (Clarke 2005). In the final stage, we gleaned the data and did another round of more focused coding. We identified usable examples of each of our themes to include in this analysis.

Data analysis was enriched by our collaborative ethnographic methodological approach. Field observations and data interpretation reflected our varying structural positions and perspectives while also allowing for a more judicious and well-rounded examination of the data (Belgrave and Smith 1995). When occasional analytical disagreements arose, they were usually due to gaps in the Crystal's knowledge about Turkish culture. For example, there were times when she would observe something unfamiliar during a ladies-only event or question gender segregation at TCC events-which Eyup could explain based on his intimate knowledge of Turkish culture. The opposite also occurred. Eyup, for example, would dismiss the significance of a particular observation or interview response that Crystal found compelling. Most often these discrepancies facilitated dialogue between researchers and enabled a deeper understanding of field observations or caused a productive dispute, forcing further consideration of the matter. Generally when a conflict of interpretation arose, it signified a deeper meaning to be considered in the data than either researcher had originally understood. In sum, both researchers were in general agreement about coding schema and application. The handful of coding discrepancies that occurred were either due to simple error or resolved through discussion.

Occupying different status positions in the field meant reflexivity was crucial throughout the research process. We utilized methodological and analytical tactics for reflexivity to track our varying positional ties in the field. Gender, language, national origin, age, marital status, and connections with the community influenced when/where we were alternatively seen/treated as insider(s) or outsider(s). For example, as an American female, Crystal could attend the ladies cooking class whereas Eyup, a Turkish male, was quickly approached (at the door) and told the event was "ladies only." On other occasions, such as a religious celebration conducted in Turkish, Eyup could understand the ceremony and, as a man, was offered a seat in the front of the room where he could better see the presentation. Crystal did not speak Turkish and, as a woman, was not granted that level of access. In addition, as an American woman and a Turkish man conducting research together in an institutional space governed (at least partially) by Turkish cultural norms, we were cognizant of what our status as a mixed-gender research team meant to 
participants. We carefully managed gender boundaries at TCC by generally avoiding initiation of cross-gender social contact in order to uphold Muslim custom and protect the comfort of our subjects. However, Crystal was occasionally able to violate gender-segregation norms in ways that Eyup could not because of Turkish participants' assumptions that, as an American, she was naïve to such interactional customs (Hewitt and Alqahtani 2003). Gathering multiple forms of data - ethnographic, interview, textual, and reflexive - from our dual positions enabled the analysis of stigma/stereotype management strategies that follows.

\section{Challenging Muslim Stigmatization at the TCC}

Anti-Muslim stigma is a very real component of Muslim Americans' lives (Cainkar 2009; Panagopoulos 2006; Rippy and Newman 2006), including the participants at TCC. The TCC's affiliation with the Gülen movement leads its efforts to focus largely on intercultural/interfaith exchanges as a remedy for anti-Muslim sentiment in the United States. Conversation about explicit negative Muslim stereotypes arose only infrequently at formally organized TCC events. Instead, there was a tacit understanding between Americans and Turks that Muslims in the West are stigmatized. One of the TCC's main objectives was to have participants confront negative stereotypes assigned to Muslims and subject them to critical analysis. This was accomplished using a practice Turks at the TCC call "dialogue." A feature in all three Abrahamic religions, dialogue is particularly common among followers of Islam; prophets of the Qur'an are cited as the ecumenical origin of dialogue (Kurucan and Erol 2012). Muslims who are members of the Gülen movement, like those at the TCC, stress the importance of intercultural/interfaith dialogue and are therefore especially likely to utilize this practice (Ebaugh 2010; Gülen 2004).

Dialogue, however, is not unique to Abrahamic religions nor is it unique to the Gülen movement itself. Scholars have analyzed its role in the resolution of community conflicts (Lohmann and Van Til 2011; Saunders and Parker 2011); citizen engagement, politics, and social work (Van Til 2011); and team-based and/or organizational learning (Dixon 1996; Senge 1999). Across these contexts, dialogue plays an important role in producing collective change via meaning-making among individuals and groups (Bohm 2004; Dixon 1996). Unlike debate or discussion, where participants intend to justify an assertion or convince others of the validity of his/her claim, dialogue is a process of constructive listening wherein communicators suspend preconceived assumptions and are open to alternative perspectives (Bohm 2004; Dixon 1996; Lohmann and Van Til 2011; Senge 1999). It is intended to "move us out of our isolated existence and beyond our restricted views" via a structured and 
sustained process wherein boundaries can dissolve and healing relationships or friendships can be forged (Lohmann and Van Til 2011, p. 19).

For Turkish participants at TCC, dialogue is understood in these terms. It is meant to inculcate knowledge and understanding through meaningful interpersonal interaction (Gülen 2004; Kurucan and Erol 2012). As, Bekir, a male Turkish TCC participant, put it, dialogue "means meeting people like you [gestures to Crystal]" and "thinking about something different in culture." When asked to elaborate, he stated that when he was new to the United States, people asked him questions about Turkey that he had never heard before-questions that revealed their misconceptions. "Because they don't know our culture," he said, "they think that we are [ruthless] with people, we are cutting their arms if they steal something. Like that, you know?" He located these misunderstandings in lack of interpersonal interaction and framed dialogue as a solution. "Because we do not have any conversation with them, they don't know us, we don't know them, but that's why we have to tell them," he asserted.

Unlike traditional applications of the practice, where all parties recognize that they are engaging in dialogue and understand what it means to do so (Bohm 2004; Senge 1999), at the TCC, Turks understand the organization's goal of using dialogue to dispel stigma, but Americans are either unaware of the term or do not fully understand its meaning. Instead, Turks regularly prompt American participants to suspend their assumptions about Muslims and to accept an alternative worldview where Muslims are not all violent. Turks believe that dialogue, as embedded in face-to-face interaction, will increase familiarity and encourage understanding, acceptance, and stigma transformation. As Yilmaz put it: "People are enemies to what they don't know." Dialogue is a means for TCC members to turn would-be "enemies" (i.e. "normals" or nonstigmatized persons) into the "wise" - people who become "intimately privy" to the lives of a stigmatized group and therefore sympathetic with them (Goffman 1963, p. 28). They accomplish this by prioritizing secular selves via cultural education, normalizing the Muslim self in conversation about religion, and presenting gendered versions of Turkish identity.

\section{Prioritizing the Secular Self: Dialogue via Cultural Education}

The presence of many headscarf-adorned women and frequent discourse likening Islam to Christianity might lead the casual American onlooker to assume that the TCC is a religious organization. However, attending TCC events quickly reveals that the organization places significantly more emphasis on nationality and secular Turkish culture than religion. ${ }^{6}$ Two factors help explain why participants frame the TCC as a cultural rather than a religious space. 
First, highlighting secular Turkish culture and deemphasizing Islam allows Turks to resist negative Muslim stereotypes. Second, in contrast to many Muslim groups around the world, though more than 99.8 percent of Turks associate with the Islamic faith (Central Intelligence Agency 2014), they identify as a secular people (A. Kaya 2010). Accordingly, Selim, a Turkish man, told us that while often "culture and faith are hard to distinguish," the TCC does not represent the "religious side." As an American woman put it, the cultural center is, "not an Islamic sect ... but a Turkish sect."

Making the TCC a primarily cultural rather than religious space means Turkish participants walk a symbolic tightrope separating nationality from religion. Many of them, similar to other followers of Gülen, are in the United States seeking the freedom of religious expression they were not provided in Turkey. In addition, spirituality is embedded in the institutional mission of the TCC, which defines the cultural center as a "multicultural, faith-based organization, operating for spiritual and educational purposes" and religion is a forefront concern for many Turkish TCC participants. Still, they regularly emphasize (in word and in practice) how nonreligious the organization's focus is. They do this using the primary form of dialogue at TCC: cultural education.

Rather than being an explicitly stated goal or task, dialogue is embedded in formal public events at the center as well as abroad - events that focus on culture rather than religion. At language classes, cooking classes, Ladies' Coffee Night, book club, spiritual dialogue meetings, the TCC Annual Dinner, and the Dialogue Trips to Turkey, Turkish participants present something unique about their culture, provide direct opportunities for Americans and Turks to participate in and experience it, and accept praise and accolades from attendees. For example, TCC-sponsored Dialogue Trips to Turkey, a feature of many Gülen-affiliated cultural groups (Ebaugh 2010), offer Americans an opportunity to not only visit Turkey, but stay in the homes of local Turks and visit mosques, government buildings, nonprofit organizations, and corporate-run facilities that they would not otherwise have access to as a tourist. Frank, an American TCC participant, described his excursion as, "a wonderful experience," explaining that a male Turkish TCC leader had arranged for the American travelers to tour a Turkish school:

After dinner that night at the school, we all split up, and went home with a Turkish family and spent the night in their home...it was just an incredible experience, to be able to do something like this, I mean, you could spend a lot of money for a tour and never get that kind of experience where you are actually spending time in Turkish people's homes and getting to know them on a real level. 
Moreover, recruitment presentations for these trips provide fodder for localized cultural education at the TCC itself. The presentations feature Turkish organizers as well as former American travelers who present pictures and tell stories from their trips encouraging interested Americans to join the next Dialogue Trip to Turkey. Both the trips and the recruitment presentations highlight unique aspects of Turkish culture and provide Americans access to Turks on a "real level" where one can engage in conversations and share experiences that, as Frank identifies, a tourist would not otherwise have.

Similar processes take place in classes and other gatherings at the center. The women's cooking class involves Turkish women presenting a cooking demonstration for an audience of mostly American TCC participants. They feature dishes from all over Turkey, often differing by region in preparation techniques. A typical menu might include bulgurlu mercimek salatasi (cracked wheat and lentil salad), kashk-e badejmjan (eggplant spread), talas boregi (talash lamb pastry) and kalburabasti (walnut cookies in syrup). To encourage participation and familiarity with the food, Turkish women often ask Americans to help complete the meal and offer hand embroidered headscarves as prizes to those who try the recipe at home and report their experience. Reflecting on her experience in these classes, Patricia, an American participant, told Crystal in the presence and to the delight of the Turkish cooking demonstrators, "I like Turkish food very much. ... [The cooking class is] a lot of fun and very interesting. It's informal and pleasant and of course the women are so friendly-it's a nice experience."

Emma, an American female participant, reacted to a "Henna Night" (a special ladies-only event) presentation, which was comparable in format to the cooking class, with a similar sentiment:

It's been this warming influence of being able to see the cultural similarities and how people - how Turkish people and local people do things similarly. The orientation towards family and the pride in their cooking [and culture]. So that's just a nice feeling.

While the concept of dialogue is not formally introduced to Americans at these events, it guides the actions of Turkish participants, who are focused on reshaping the ways Americans think about Turkish culture/people by making them more familiar with it/them (Bohm 2004; Dixon 1996; Senge 1999). Meaningful interpersonal interactions at these events help dissolve boundaries and create a space for Americans to become, as Turks often put it, their "friends" (Gülen 2004; Lohmann and Van Til 2011). As Emma's comments suggest, one way Turkish members accomplish this is by normalizing Turkish culture/people for Americans. When they offer headscarves as prizes at 
cooking class or offer hands-on experience with food, art, and language, Turkish practices become "similar" to what "local people" do, producing "nice feeling[s]" and experiences for American participants.

This approach is common for Turkish people, even in other contexts. Turks often emphasize the complexity of their identities by focusing on similarities with European culture and disassociating with negatively stigmatized groups like Arabs (A. Kaya 2010). At TCC, as in countries where Turks have well-established historic migration patterns, prioritizing and emphasizing national identity/culture facilitates stigma management (Abadan-Unat 1995).

Providing Americans with experiences that normalize artifacts of Turkish culture and stress the similarity of Turkish and American practices challenges negative stereotypes about Turks/Muslims via contiguity claims. Contiguity claims are arguments meant to reinforce the message that a group has been inappropriately stigmatized by pointing out its similarity to a nondeviant group (Berbrier 2002, p. 560). At TCC, Turks use practices that instill familiarity through interpersonal interaction. This leads Americans to make contiguity claims about Turks' similarity to "local people" without Turkish participants directly making assertions themselves.

However, Americans who participate in hands-on experiences like traveling to Turkey and participating in cooking classes also occasionally frame Turkish culture as magical, distant, or unfamiliar. For example, many Americans who traveled to Turkey as part of a Dialogue Trip described their experiences as almost surreal. Helen, a female American TCC participant, said that Turkey, "captivated [her] imagination," evoking a mystical sort of imagery as she described her travels through the Turkish countryside. Framing Turkey/Turkish culture in this way does occur on a local level as well. For example, the TCC sponsors a monthly Ladies Coffee Night. Anywhere from five to twenty Turkish women and three to fifteen American women attend. One coffee night involved showing attendees how to brew Turkish coffee. Another featured a local artist who demonstrated Ebru, a painting/paper marbling technique prominent in Turkish art, described here in Crystal's field notes:

Fatos explained that the water in the pan that was to be used for Ebru was not normal tap water, but special water treated with animal fat so the paint doesn't drop to the bottom, but floats on top of it. She described that the jars full of colorful watery paint were made from natural dyes and not chemicals. The artist dipped the painting needle in green paint and drew a long, horizontal, slightly curved line across the water, like the stem of a flower and its leaves. She then dropped dots of yellow and red around the stem for the flowers and began to manipulate the dots with the needle. Each time she made a stroke in one dot, creating the form of a flower petal. 
Fatos, a female Turk, began to describe the cultural significance and philosophy behind the art. For example, while the artist used equal, dedicated needle strokes to create each petal for the flower in her first painting, Fatos explained that, "Ebru is about balance and what you do to one, you have to do to all of the others." She also informed participants that religious symbolism is frequently used in Ebru art, which often depicts a rose - symbolizing the Muslim prophet Mohammad, who is himself a rose in the desert - and a tulip, which represents God.

During Fatos' presentation, as the artist started a second painting, Samantha, an American TCC participant, exclaimed, "It's like magic every time!" Samantha's sentiment is illustrative of the sometimes-mysterious nature of Turkish culture for Americans. Highlighting the beauty of Turkish art and describing its symbolism/creation to Americans makes Turkish culture accessible and facilitates the reconceptualization of the Muslim image in their minds. However, unlike Emma's and Patricia's reactions to cooking classes and henna night — which stress similarity and amount to contiguity claims (Berbrier 2002) - Helen's imaginative relationship with the Turkish landscape and Samantha's experiences with Ebru stresses the beautiful strangeness of Turkish culture. While both reactions combat anti-Muslim stigma by putting Turkish culture and the secular self on the forefront, they also reinforce Orientalism (Said 1979, 1980). Westerners fetishizing Turkish culture as "magic" perpetuates the view that Eastern culture(s) are exotic and fundamentally different than the West, just as assessing them positively because they are similar to Western practices reinforces their inferior hierarchical position relative to Western culture.

\section{Normalizing the Muslim Self: American-Prompted Religious Dialogue}

Evident in displays of Turkish culture as presented above, Turks at the TCC draw upon the more innocuous component of their identities, that of their nationality, to introduce components of their religious identity. When the Turkish ladies offer headscarves as prizes during cooking classes or describe the religious significance of traditional Ebru imagery, for example, they are seizing an opportunity to introduce Islam/Islamic traditions into the mindset of American participants thus commandeering the American participants' newly formed familiarity with Turkish culture as a vehicle for the normalization of the Muslim identity while still prioritizing culture over religion. Turks at the TCC do not directly confront negative Muslim stereotypes, but rather use dialogue to gently correct them. Therefore, a second form of dialogue at 
the TCC involves creating familiarity through informal conversation. As the Ladies' Coffee Night leader told attendees, "the aim of [Coffee Nights] is to promote diversity and encourage ladies from many different cultures to gather and have a delightful time while making new friends! [We are] opening our hearts to you and hope to get to know you better."

This aspect of dialogue is most visible to American participants. As Ann, an American woman and frequent TCC participant explained, "a big part of [the TCC], is just to have people see who they are, to put aside stereotypes, a 'this is what we are, you can ask us anything' sort of thing." Frank, an American man and former member of the BOD agreed:

That's why I think that what they are doing [at the TCC] is so great because really, fundamentally what they want to do is encourage people to talk to one another about where they are in their culture, in their faith and just understand each other a little better and that's why they're so big on having these meetings over meals and all of that.

Turkish TCC participants, aware that informal conversation provides a unique opportunity for open-ended dialogue, are deliberate when choosing seats at events like the annual dinner or coffee nights. At these events, American participants usually sit with whomever they arrived or individuals they already know. Non-English-speaking Turkish participants often sit apart from the rest of the group. English-speaking Turkish TCC participants, however, scatter themselves around the room purposefully, ensuring that they are with a group of Americans and are optimally available for conversation or informal dialogue.

Unlike formal events, which are largely controlled by Turkish participants and center on culture, Americans play a bigger role in steering dialogue during informal conversation. Turkish participants resist centering their Muslim identities, but when Americans prompt dialogue, it most often revolves around religious inquiry and their curiosity about Islam. While this provides Turks another opportunity to manage stigma, it also means that rather than presenting positive images and accepting accolades (as happens with cultural education efforts and in informal conversations about culture), they must correct negative stereotypes. Most frequently, they accomplish this by making contiguity claims that demonstrate and emphasize the similarities between Islam and Christianity-sending the message "we are like you" (Berbrier 2002). For example, Gulay, a Turkish woman, said:

A Christian may believe that Muslims really don't like Jesus at all, but they have never heard our point of view about Jesus. And when they hear the story 
in the Qur'an, for example - we have a special chapter for Marym, Mary in the Bible, Marym in Turkish, with her name, just with her name - and we have Jesus' story and her story and all the details in the Qur'an.

She continues, talking about her experiences sharing this information with Americans:

When we first shared this with them, then they were amazed that we love Jesus like any other Prophet, too. So they might start thinking there must be some educated, open-minded, or more conscious Muslims. They know their religion, their religion doesn't teach them to be enemies. They learn that our Qur'an and God tell us to love neighbors, too, like Christians say—so they shouldn't be an enemy to us.

Gulay's example illustrates how direct interfaith dialogue in informal conversation about prophets, biblical content, or philosophical beliefs, when focused on similarities, can break down Americans' belief that they should be "an enemy to [Turkish Muslims]" and challenge the notion that Muslims or Turkish people are inclined toward violence. Other times, interfaith dialogue is less about core beliefs or texts, but instead revolves around practices and the day-to-day experience of faith. At one coffee night, for example, Maria, an American Catholic nun, tugged on the blue cloth covering her head and made a comment about her hair always coming out. Yonca, a Turkish woman, empathized with Maria's discomfort and showed her the beige-colored cap she wore underneath her colorful headscarf to prevent her hair from being seen. She offered to get Maria some caps if she would like. Maria declined Yonca's offer, but after this exchange uncovering similarities in their daily experience of religious practice, they began discussing the women of the bible.

While Turkish participants often describe differences making people "more valuable" to one another, as Yilmaz put it, they usually stress religious similarities in these conversations. Here, as with their presentations of Turkish culture and the Turkish secular self, they find ways to (as Gulay said) "[find] similarities and [talk] about them" so that Americans and Turks will be closer and "won't see each other as enemies." Again, their efforts amount to contiguity claims that happen without Turks making direct "we are like you" assertions to Americans (Berbrier 2002). However, "distancing claims"-which do involve direct assertions about Turkish Muslims-also emerged in conversations about religion (Berbrier 2002). Distancing claims are claims aimed at distinguishing nondeviant group members from deviant group members by arguing "we are not them." 
Distancing claims are a common stigma management technique (Barkdull et al. 2011) and often co-occur with contiguity claims (Hutchison et al. 2008). Some scholars call this the "black sheep effect," where members of an ingroup attempt to preserve the group's integrity by degrading, disassociating with, and/or making extreme judgments about their noncompliant peers (Johns, Schmader, and Lickel 2005; Marques, Yzerbyt, and Leyens 1988). Turks at the TCC frequently do this when confronted with negative stereotypes about Turkish Muslims during religious dialogue with Americans. They draw sharp distinctions between "good" and "bad" Muslims. For example, Gulay said:

[Americans] ask, "What are those terrorist people doing, why do they do this?" And we try to explain that they misunderstand - on purpose maybe - things in Qur'an. And when they understand even some Christians may use Bible wrongly, there are some Muslim people who use the Qur'an in the wrong way too, then they don't have to [see] every Muslim as [a] terrorist.

During one Annual TCC Dinner, a renowned Turkish author similarly distanced Turks from the Muslims who executed the 9/11 attacks. He asked the audience to consider how Turks might view Americans if the image of a whole nation was based on one incident:

As someone in the media, I know, we all know, that the media inevitably portrays us as not the nicest people on the other side. The media inevitably portrays us actually in the most shocking, the most unacceptable, the most disturbing elements of a foreign society, a foreign civilization. In other words, here in the U.S., the Muslims who make the news are generally not the nicest Muslims in the world. So far the people who say the most unacceptable things or do the most shocking things [are the ones who are shown to the world]. But millions and millions of Muslims who disagree with [their actions are not given a voice]. But let me tell you though, the same dynamic is working on our side of the front. In other words, Americans or westerners who make the news on our side are not always the nicest [or those who] give the nicest message.

He continued, describing how he did a Google search on Christian leaders in the West and that the most frequently cited Christian leader was a Florida man who burned the Qur'an. He said though he knew that the majority of Christians in the West would disagree with this act, those not familiar with American culture might assume all Christians feel this way. He warned his audience to push beyond "seeing the most disturbing elements of the other side."

While Turkish participants prefer an approach to dialogue that involves putting culture and secular selfhood at the forefront, when religion arises in 
informal conversation, it provides them an opportunity to grapple with the root of negative Muslim stigmas. As such, Turkish TCC participants purposely remain open to talking about religion when American participants bring it up. They typically use this form of dialogue to make indirect contiguity claims about Christianity and Islam. Occasionally, however, elements of "new" Orientalism - a view that positions Islam as particularly violent (Alam 2006; Tuastad 2003) — appear in Turkish/American exchanges about religion. When this happens, Turks used distancing claims to argue they are not like the 9/11 terrorists. As Yonca put it, "Not all Muslims are like those who bombed the Twin Towers."

Islam and (by extension) Turkish culture are subject to negative judgment when Americans steer the conversation toward religion. Turkish participants responding with distancing and contiguity claims, while buffering TCC members from stigmatization and challenging negative stereotypes, maintain the broader inequality between the West/Christianity and the East/Islam. When making distance claims, Turks

admit and presume the existence of sick, diseased, or violent people [in this case, Muslim terrorists] (and imply that they might need to be dealt with via mechanisms of social control), but argue that those people are to be found elsewhere, far away from "us" [Turks at TCC]. (Berbrier 2002, p. 561)

With contiguity claims, Turks keep intact the inequality between Eastern/ Western religions by maintaining American culture and/or Christianity as the standard against which other cultures and religions should be compared (Hage 1998; Lentin and Titley 2011). Unlike Turkish culture and Islam, American culture and religious traditions are never problematized in this framework.

\section{Dialogue Embodied: Gendered Presentation(s) of the Turkish Muslim Self}

Aside from formal cultural education and informal dialogue, stigma management also occurs through Turkish TCC participants' embodiment of core Islamic ideologies, especially as expressed in the teachings of Fethullah Gülen: hospitality, generosity, peace, kindness, tolerance, and acceptance. Through their mannerisms, demeanor, and speech, Turks at the TCC dispel negative stereotypes that suggest Muslims are violent people. They demonstrate to Americans that Turks, as Gulay says, "love [their] neighbors too." While both men and women engage in cultural education efforts and conversations about religion at TCC, Turkish women play a primary role in this 
informal, unstated form of "dialogue." Our field notes are full of commentary about Turkish women's kindness, patience, and accessibility. As Crystal's field notes say about Yonca: "Yonca speaks with such calm and concentration. It is always a pleasure for me to talk with her," and "Yonca said all of this looking at me, focused despite the bustle around us, with her usual happy eyes." Fatos, a Turkish TCC member, is also featured in Crystal's field notes. Fatos is described as: "A lady who I have grown to respect and appreciate very much, [especially] her kind, soft, articulate and polite manner. She always seems genuinely interested in everything that anyone has to say." Fatos, an educator by trade, was ever ready to clarify a particular cultural element, difference, and/or tradition for Crystal. She often walked Crystal through ceremonies, providing detailed explanations of the ingredients in a particular Turkish dish, the story behind a religious custom, or a description of the symbols evident in Turkish/Muslim art.

For example, in her explanation of an Islamic sacrifice festival's rituals, while describing the meat eaten after the sacrifice, Fatos noticed that Crystal did not have meat on her plate. Out of respect and understanding, she ended her story:

Fatos began to speak to me about how much she and others loved the meat for this festival because it always tasted so fresh and flavorful. Nur also made a comment like this as she overheard our conversation. But then Fatos looked at my plate and noticed that I had not taken any meat. She asked if I was vegetarian and then stopped describing why she liked the meat. I told her I wanted to hear about it and requested that she continue.

Fatos did not want to offend Crystal by discussing the meat, the reason for the sacrifice, and what the Turks at the TCC seemed to enjoy most about the celebration, thus demonstrating both kindness, tolerance, and respect for cultural traditions different from her own. Fatos' attentiveness to and sensitivity toward even the subtlest cultural cues (the contents of Crystal's plate), is so finely tuned that she pushes beyond normal kindness, patience, and willingness to communicate. She exhibited a sense of tolerance and mutual respect toward one's alternative life perspectives that embodies the spirit of dialogue.

As these field note excerpts suggest, Turkish women occupy a central role in embodying a gendered version of the kind, respectful Muslim self-for them, a physical manifestation of dialogue. The same is true for expressions of hospitality and generosity - two other ideals Turkish participants emphasize in their interactions with Americans. Food is one vehicle for this work. As Alice once exclaimed, "and food - there's always food, for every event! 
(laughing) Even at a committee meeting, we turn around and there's food on the table or a cup of tea!" Indeed, more home cooked Turkish cuisine than any group twice the size of those attending could eat appeared at every TCC event. Turkish women prepare and serve this food to guests, as Eyup's field notes document:

After the speech, guests, who finished eating their meals, slowly began to leave the building. While some of the guests were leaving, Turkish ladies, who prepared the meals, started to tidy up the living room. I intended to help the ladies to neaten up the living room. When I attempted to help them, one of them suggests [that I] drink a cup of tea. She said: "You are a guest, please don't disturb yourself."

Turks at TCC also express hospitality and generosity through financial contributions. This was the one arena where Turkish men's labor is as visible as women's work. However, here, too, presentations of self that challenge Western assumptions about the violent nature of Islam and/or Turkish culture are deeply gendered (Alam 2006; Tuastad 2003). Turkish TCC leaders often suggest a fee on event flyers or website advertisements, but fees are never formally collected or enforced. Instead, Turkish participants finance events largely with funds out of their own pockets. As Suleyman, a Turkish male participant, explained,

Turks help to organize the activities. For example, Turkish ladies prepare most of the food for the activities and they don't want any money for these preparations. [They prepared food with their own means] voluntarily. And for the other expenses like the rent of the building of TCC, people who come here donate. I donate too.

Suleyman's comments reflect how Turkish men disproportionately fund core TCC needs such as rent/utilities and TCC events. Their structural position (Turkish men at TCC are more likely than Turkish women to earn wages, have access to money, and/or to control family funds) positions them to be capable of this sort of generosity in a way most women are not. However, women, as Suleyman indicated when he said they "prepare most of the food for the activities" and do not want compensation for it, still play a primary role in embodying a gendered version of the generous Turkish Muslim self. They do this for TCC and for other local organizations. For example, TCC's annual fundraiser features homemade food for sale, Turkish goods like rugs and clothes, and a garage sale with items mostly donated by the Turks themselves. Profits go to a local cause - most recently, a local elementary school. As Selim described it: 
The ladies put their own effort and time in preparing all those dishes, and they get a small fee from the people who are attending [the cooking classes], and they actually had some extras, profit, and with that profit they bought the ingredients for the food, which they sold at the event. I think it is a great sense of entrepreneurship, social responsibility. And half of the money-or maybe more than half-was donated to the school, which is in need. So it is not a big amount, but at the end of the day you do something for the society.

Personal contributions to the local community such as these align with the importance that Gülen followers place on hospitality and generosity as core Muslim values, particularly in relation to interpersonal interactions as well as open support of educational institutions (via their financial support of a local school). Moreover, these contributions - primarily made by Turkish women-illustrate to Americans that Turks do not embody the negative stereotypes that suggest Muslims hate America or the West. To the contrary, their generosity toward schools and organizations in their city illustrates that they are active, responsible community members.

Turkish women's embodiment of Muslim ideals like patience, tolerance, and generosity often extends outside the community center in this manner, as Gulay's comments suggest:

Through [TCC] we have been meeting a lot [of American friends]. I [tell them] if they need anything, if they have a party, we want to cook for them, to help. If someone invites me, I try to take a plate, too, because I know she will be tired. We started to take care of each other, too. I mean, I invite them to my house then they invite us to their house and they ask about the kids, how they are doing. They even met my father and mother. We even visited their church [and] attended their holiday prayer.

Similarly extending her generosity beyond the confines of TCC, Fatma, a female Turk, frequently offered Crystal rides to events. When Crystal offered to provide Fatma compensation for the rides, Fatma refused:

At this point we stopped for gas down the street from [Crystal's] apartment and I offered to chip in for gas money and she sternly, but half-jokingly stated, "Don't offer that. If you do, I'll get mad."

Crystal and Eyup's experiences with the generosity of Turks - especially Turkish women - at TCC are typical of American participants. Frank's comments illustrate how many felt about it:

The hospitality - it's not just the going into the homes [of the Turks] that's a big deal, but it's the feeling that you are like visiting royalty in this home, and they 
treat you so well when you come. You just feel like an honored guest from beginning to end and that the thing that people enjoy so much is how well they are treated. If you wanted to talk about books, that's great too. If you want to go to Turkey with them, that's great. They are just - they're very good about finding your comfort level for engaging with them and not pushing you beyond that. Just letting you find your way into their world and into that friendship.

Americans who are exposed to Turks' embodied presentations of a peaceful, generous, respectful, and hospitable Turkish/Muslim self feel like "visiting royalty" whose "comfort level" is respected and whose friendship is sought. Turks' gendered embodiment of Muslim ideals tacitly fosters dialogue and helps deconstruct the image of Muslims and/or Turks as hostile, angry, or violent people (Alam 2006; Tuastad 2003). As we saw when dialogue took the form of cultural education and informal conversation about religion, most of this work is done without Turks ever making direct assertions. Just like exposure to Turkish culture leads Americans to see the contiguity between Turks and themselves, exposure to Turkish women's embodied presentations of self lead Americans to see the distance between Turks at the TCC and the "black sheep" they might otherwise be associated with (i.e. terrorists/extremists; Berbrier 2002; Marques, Yzerbyt, and Leyens 1988). This approach, like many other projects that attempt to bring Eastern cultures into dialogue with the West, feminizes Turkish culture, customs, and/or Muslim religious traditions (Maira 2008; Yan and Santos 2009), in order to make them more palatable and safer for American audiences. While performances of respect, peacefulness, and generosity work to challenge anti-Muslim stigma, they simultaneously reproduce longstanding stereotypes of Muslim women as passive victims of strict Muslim gender regimes (Lentin and Titley 2011; Saloom 2005).

\section{Discussion and Conclusion}

As members of the Gülen movement, Turkish men and women at the TCC manage stigma and challenge negative stereotypes about Muslims through the practice of dialogue. Embedded in formal cultural education efforts; intimate conversations about religion; and in gendered presentation(s) of self, dialogue allows Turks to make contiguity claims that stress their similarity to Americans and/or Christians and distancing claims that stress their dissimilarity from terrorists/extremists (Berbrier 2002). When Turkish TCC participants engage in dialogue through cultural education - a process they control and use to emphasize the secular Turkish self - they cultivate a familiarity with Turkish culture that leads many Americans to conclude "they are like 
us." In informal conversation, Turks dispel Americans' negative Muslim stereotypes by stressing the similarities between Christianity and Islam or distancing themselves from their "black sheep" brethren: 9/11 offenders. When engaging in dialogue as an embodied presentation, Turks at the TCC help Americans see the distance between themselves ("good") and "bad" (violent/ extremist) Muslims by feminizing the Muslim self.

Our ethnographic study of the TCC allowed us to examine the socially embedded nature of stigmatization processes (Collins 2004; Corrigan and Watson 2002), where "specific norms and expectations" in a microsocial institutional context shape how stigmatized groups experience and handle stigmatization (Barreto and Ellemers 2010, p. 435). We identify three factors that explain the shape and effectiveness of stigma management at the TCC. First, working collectively in an institutional space that is controlled by Turks makes adopting dialogue as a primary and uniform stigma management practice possible. Past research suggests that group-based strategies like this are effective for resilience in the face of stigmatization (Barkdull et al. 2011; O'Brien 2011; Umbreit Lewis, and Burns 2003) and that they provide important self-protective benefits to individuals managing stigma (Crabtree et al. 2010; Leach et al. 2010; Valenta 2009). Second, the social and cultural background of Muslims at the TCC (as Turks and followers of Gülen) explains their embracing dialogue and prioritizing secular rather than religious identity (A. Kaya 2010; Turam 2004). Our work suggests this is a strategy Americans find more palatable than those involving stronger identification with Islam, which run the risk of incurring further stigmatization because Muslims are perceived as resisting assimilation (Barkdull et al. 2011; Klandermans, van der Toorn, and van Stekelenburg 2008). Finally, gender norms shape participants' embodiment of the peaceful/generous Turkish/ Muslim self at the TCC. Feminizing Islam and/or Eastern cultures is appealing to Western audiences (Yan and Santos 2009). Our work suggests this practice can therefore facilitate stigma management.

In addition to examining the contextual norms and expectations that explain Turks' use of dialogue to manage stigma, we also contribute to recent stigmatization research on social structural influences by using critical race theory to interrogate the "power situations" that contextual norms and expectations unfold in (Barreto and Ellemers 2010; Scambler 2006). At first glance, Turks' efforts to challenge and resist stigmatization could be seen as an attempt at stigma transformation (Pfuhl 1993) - a process whereby groups use "moral entrepreneurship strategies" to change the meaning of a deviant label, which has broad consequences for reframing how society sees a stigmatized group (Becker 1963; Berbrier 2002). After all, Turks at the TCC utilize a "home culture" frame: one they (the stigmatized group, in this case 
Turks at the TCC) developed in response to negative stereotypes and which contains positive, affirming messages about their culture (Feagin 2009). In addition, especially as followers of Gülen, they see their efforts as part of a larger social movement that will fundamentally transform the way Americans perceive Islam (Ebaugh 2010).

Upon closer examination, however, it is clear that while TCC Turks' use of dialogue helps them personally manage stigma and helps deconstruct negative images of Muslims and Turks in the minds of Americans at the center itself, it simultaneously perpetuates broader patterns of racial/ethnic and gender inequality. Stigmatized groups' psychological orientations to the self have historically been connected to the way they are viewed in mainstream (i.e. white) America (Du Bois 1903; Fanon 1967). Turks at the TCC are no exception. Their presentations of self-especially because they are aimed at an American audience - continually engage with Orientalist views of Islam and the East. When Turks at TCC make claims such as "we are like you" or "we are not those Muslims" and when they use a feminized version of the Turkish self to challenge stigma, they frame themselves as exceptions to the rule: more peaceful, more kind, more normal or "like you" than Muslim extremists. This leaves the general stereotype of Muslims as violent extremists intact, however. It also perpetuates stereotypes of Muslim women as passive victims of extreme gender regimes and reinforces the West/Christianity as the standard against which other cultures/religions should be assessed (Said 1979, 1980). In other words, rather than deconstructing the "deviant cultural space" that Muslims occupy in the United States, Turkish TCC participants' stigma management practices do not question the existence or legitimacy of that space, but merely challenge their placement within it (Berbrier 2002, p. 561).

This is similar to what Crenshaw (2011, p. 1332) calls "post-racial pragmatism," or "an adjustment to and negotiation within existing power while ensuring that such power remains unmarked." Others call strategies like those we observed at TCC "self-Orientalism" (Yan and Santos 2009) or "selfexoticism" (Shay and Sellers-Young 2003). Our work suggests these strategies are intimately tied to the social structural positions that the people and groups who utilize them occupy. Turks at TCC are relatively privileged by comparison to poorer or more marginalized Muslims and/or Turkish people in the United States. Their relatively secure class status makes it easier to view cultural ignorance or lack of "knowing each other" as the core cause of stigma - a view scholars would argue blankets the structural forces influencing the development/perpetuation of stigma that cannot be easily resolved through interpersonal communication (Goffman 1963; Scambler 2006). Rather than openly discuss the long history of unequal race/ethnic relations 
between the East and the West, Islam and Christianity, or Turks and Americans, the strategies employed by Turks at the TCC engage with existing inequalities as baggage ready to be abandoned and moved beyond. Though our analysis reveals that it is clearly steeped in inequality between the two groups, the "dialogue" strategy positions Turks and Americans as though they are (or can be) equal partners in open exchange, intimate communication, and friendship. The work Turks do at the TCC, while on the face seeming like a move toward equality and acceptance, actually involves using "dissociative gestures" to communicate lack of threat to existing Western/ white/American power structures (Crenshaw 2011, p. 1321).

While we identify specific strategies that work well for personally buffering individual members of stigmatized groups against some of the negative consequences of stigmatization, examine the contextual norms that fuel those strategies, and interrogate the role power dynamics play in the development and perpetuation of stigma, this study has important limitations. First, one of the reasons TCC's strategies are successful is selection bias. Many of the Americans who attend events at the center are more receptive to both Turkish and Muslim culture than others might be. Many American participants openly admit that they fostered an interest in Turkish culture and an open mindedness toward learning about Islam. What leads some individuals to accept invitations to TCC and whether or not the strategies used at TCC to dispel stereotypes and manage Muslim stigmatization would work with other people who are not similarly inclined deserves further investigation.

Additional future research utilizing an intersectionality approach would also greatly benefit our understanding of stigma management, especially among Muslim groups and individuals. Studies clearly reveal that status positions such as race, class, gender, nation, and sexuality affect how groups experience stigmatization processes. As our analysis reveals, particular aspects of Turkish culture (i.e. emphasis on secular identity), the financially stable class position of Turks at TCC, and traditional gender norms that feminize Islam position them well for managing stigma. Other works elucidate how the Black Muslim experience in America, for example, is different than African Muslims' experience with discrimination and stereotyping (Abdullah 2009; Barzegar 2011) or how gender norms (e.g. wearing the hijab) put Muslim women at increased risk for ill treatment at the hands of non-Muslim Americans (Barkdull et al. 2011; Endelstein and Ryan 2013). Adopting an intersectional lens would allow researchers to see the multifaceted ways in which social experiences unfold based upon differential status positionseven within groups that outsiders see as uniformly "other"- and how those variant experiences are tied to stigma management strategies. 
Finally, while our work indicates that contextual factors (e.g., an institutional context managed by Turks), aspects of Turkish culture (e.g., prioritization of secular identity), and gendered strategies (the presentation of a generous, hospitable, and peaceful self) facilitate stigma management for individuals, these strategies also reinforce longstanding patterns in Western views of the East (Said 1979, 1980; Yan and Santos 2009). Post-Orientalist and/or feminist scholarship has criticized exoticized, reductive representations of Eastern people/traditions, especially of Oriental and/or Muslim women (Saloom 2005). Our work suggests that stigma management practices are not necessarily a space for such critical analysis of institutional racism embedded in Western culture. Essentially, "Anything said in defense of Islam is more or less forced into the apologetic form of a plea for Islam's humanism, its contributions to civilization, development, and perhaps even to democratic niceness"- elements we clearly see in Turks' dialogue-based stigma management strategies at TCC (Said 1980, p. 488). Future studies might investigate stigma management strategies among less privileged Turks or Muslims and/or the employment of strategies that do not so easily "conform to Orientalist discourse" or create and sustain impressions of Muslims/Turks that remain "subjugated to Western understanding" (Yan and Santos 2009, p. 295).

\section{Declaration of Conflicting Interests}

The author(s) declared no potential conflicts of interest with respect to the research, authorship, and/or publication of this article.

\section{Funding}

The author(s) received no financial support for the research, authorship, and/or publication of this article.

\section{Notes}

1. We have changed the name of the community center and all participants in order to preserve confidentiality.

2. Perhaps due to Gülen-related political turmoil in Turkey (for an example, see Arango 2013) or additional unwanted stigma due to their association with Gülen, Turks at the TCC were not forthcoming about their affiliation with the movement. We became aware of the TCC's relationship with the Hizmet/Gülen Movement only because one of the researchers is Turkish and easily identified the association and because an American TCC participant openly discussed it with the Crystal. When asked about their association with Gülen, Turkish TCC participants evaded questions or redirected conversations. One participant questioned our motivations for even broaching the subject. In order to remain in good standing at the TCC, we therefore did not push participants to further discuss their affiliation with Gülen. 
3. Figure includes one Moroccan Muslim woman and one American Muslim woman.

4. Figure includes one white American Muslim man.

5. The division between citizenship and religious status is not simple. Only a few Turks at the TCC are American citizens and, as our membership statistics indicate, at least two Muslims at the TCC are white Americans. However, because these instances are rare, for the sake of ease, from this point on we distinguish between Turks and Americans as the primary demographic division.

6. We use the identifiers "Turkish" and "Muslim" interchangeably in our analysis. Although we and the TCC participants recognize the difference between national and religious identity, TCC participants frequently wed the two so that they are indistinguishable from one another-something that we argue aids in stigma management. We therefore occasionally use the two identifiers interchangeably.

\section{Works Cited}

Abadan-Unat, Nermin. 1995. Turkish migration to Europe. In The Cambridge survey of world migration, edited by Robin Cohen. Cambridge: Cambridge University Press, 279-84.

Abdullah, Zain. 2009. African "soul brothers" in the 'hood: Immigration, Islam, and the Black encounter. Anthropological Quarterly 82 (1): 37-62.

Abu-Raiya, Hisham, Kenneth I. Pargament, and Annette Mahoney 2011. Examining coping methods with stressful interpersonal events experienced by Muslims living in the United States following the 9/11 attacks. Psychology of Religion and Spirituality 3 (1): 1-14.

Alam, M. Shahid. 2006. Challenging the new Orientalism: Dissenting essays on the "War against Islam." North Haledon, NJ: Islamic Publications International.

Ali, Wajahat, Eli Clifton, Matthew Duss, Lee Fang, Scott Keyes, and Faiz Shakir. 2011. "Fear, Inc." The roots of the Islamophobia network in America. Washington, DC: Center for American Progress.

Allison, Katherine. 2013. American Occidentalism and the agential Muslim woman. Review of International Studies 39 (03): 665-84.

Arango, Tim. 2013, December 18. Raids and graft inquiry in Turkey are seen by some as Muslim cleric's plot. The New York Times A20.

Ayers, John W. 2007. Changing sides: 9/11 and the American Muslim voter. Review of Religious Research 49 (2): 187-98.

Ayoub, Mahmoud. 2011. 9/11 and the need for a new paradigm for interfaith dialogue. The Muslim World 101 (3): 562-64.

Barkdull, Carenlee, Khadija Khaja, Irene Queiro-Tajalli, Amy Swart, Diane Cunningham, and Sheila Dennis. 2011. Experiences of Muslims in four Western countries post-9/11. Affilia 26 (2): 139-53.

Barreto, Manuela, and Ellemers, Naomi. 2010. Current issues in the study of social stigma: Some controversies and unresolved issues. Journal of Social Issues 66 (3): $431-45$. 
Barzegar, Abbas. 2011. Discourse, identity, and community: Problems and prospects in the study of Islam in America. Muslim World 101 (3): 511-38.

BBC World News. 2013, December 18. Profile: Fethullah Gulen's Hizmet movement. Retrieved December 2, 2014. http://www.bbc.com/news/world-13503361.

Becker, Howard S. 1963. Outsiders: Studies in the sociology of deviance. New York: Free Press.

Belgrave, Linda Liska, and Keruleth J. Smith. 1995. Negotiated validity in collaborative ethnography. Qualitative Inquiry 1 (1): 69-86.

Berbrier, Mitch. 2002. Making minorities: Cultural space, stigma transformation frames, and the categorical status claims of deaf, gay, and white supremacist activists in late twentieth century America. Sociological Forum 17 (4): 553-91.

Bleich, Erik. 2009. Muslims and the state in the post-9/11 West: Introduction. Journal of Ethnic and Migration Studies 35 (3): 353-60.

Bohm, David. 2004. On dialogue, second edition. New York: Routledge.

Bonet, Sally Wesley. 2011. Educating Muslim American youth in a post-9/11 era: A critical review of policy and practice. High School Journal 95 (1): 46-55.

Bonilla-Silva, Eduardo. 2010. Racism without racists, third edition. Lanham, MD: Rowman and Littlefield Publishers.

Brennan, Sue. 2011. Time, space, and national belonging in The Namesake: Redrawing South Asian American citizenship in the shadow of 9/11. Journal of Transnational American Studies 3 (1).

Cainkar, Louise. 2009. Homeland insecurity: The Arab American and Muslim American experience after 9/11. New York: Russell Sage Foundation.

Carr, Deborah, and Michael A. Friedman. 2005. Is obesity stigmatizing? Body weight, perceived discrimination, and psychological well-being in the United States. Journal of Health and Social Behavior 46 (3): 244-59.

Central Intelligence Agency. 2014. The world factbook: Middle East, Turkey. Washington, DC: Central Intelligence Agency.

Charmaz, Kathy. 2006. Constructing grounded theory: A practical guide through qualitative analysis. Thousand Oaks, CA: SAGE.

Chou, Rosalind S., and Joe R. Feagin. 2008. The myth of the model minority: Asian Americans facing racism. Boulder: Paradigm Publishers.

Clarke, Adele E. 2005. Situational analysis: Grounded theory after the postmodern turn. Thousand Oaks, CA: Sage.

Collins, Patricia Hill. 2004. Black sexual politics: African Americans, gender, and the new racism. New York: Routledge.

Corrigan, Patrick W., and Amy C. Watson. 2002. The paradox of self-stigma and mental illness. Clinical Psychology: Science and Practice, 9 (1): 35-53.

Crabtree, Jason W., S. Alexander Haslam, Tom Postmes, and Catherine Haslam. 2010. Mental health support groups, stigma, and self-esteem: Positive and negative implications of group identification. Journal of Social Issues, 66 (3): 553-69.

Crenshaw, Kimberlé. 1991. Mapping the margins: Intersectionality, identity politics, and violence against women of color. Stanford Law Review 43 (6): 1241-99. 
Crenshaw, Kimberlé Williams. 2011. Twenty years of critical race theory: Looking back to move forward. Connecticut Law Review 43 (5), 1253-1352.

Dixon, Nancy. M. 1996. Perspectives on dialogue: Making talk developmental for individuals and organizations. Greensboro, NC: Center for Creative Leadership.

Du Bois, W. E. B. 1903. The souls of black folk. Chicago: A. C. McClurg \& Co.

Duster, Troy. 2003. Buried alive: The concept of race in science. In Genetic nature/ culture: Anthropology and science beyond the two-culture divide. Berkeley, CA: University of California Press.

Ebaugh, Helen Rose. 2010. The Gülen movement: A sociological analysis of a civic movement rooted in moderate Islam. New York: Springer.

el-Aswad, el-Sayed. (2013). Images of Muslims in Western scholarship and media after 9/11. Digest of Middle East Studies 22 (1): 39-56.

Endelstein, Lucine, and Louise Ryan. 2013. Dressing religious bodies in public spaces: Gender, clothing and negotiations of stigma among Jews in Paris and Muslims in London. Integrative Psychological \& Behavioral Science 47 (2): 249-64.

Esterberg, Kristin G. 2002. Qualitative Methods in Social Research. New York: McGraw-Hill Higher Education.

Fanon, Frantz. 1967. Black skin, white masks. New York: Grove Press.

Feagin, Joe R. 2009. The white racial frame: Centuries of racial framing and counterframing, first edition. New York: Routledge.

Feagin, Joe R. 2013. Systemic racism: A theory of oppression. New York: Routledge.

Fernández, Gastón A. (2007). Race, gender, and class in the persistence of the Mariel stigma twenty years after the exodus from Cuba. International Migration Review 41 (3): 602-22.

Fink, Paul Jay, and Allan Tasman. (1992). Stigma and mental illness. Arlington, VA: American Psychiatric Publishing.

Gallup, Inc. 2009. Religious perceptions in America with an in-depth analysis of U.S. attitudes toward Muslims and Islam. Washington, DC: Gallup, Inc.

Garland, David. 2001. The culture of control: crime and social order in contemporary society. Chicago: University of Chicago Press.

Ghumman, Sonia, and Linda Jackson. 2010. The downside of religious attire: The Muslim headscarf and expectations of obtaining employment. Journal of Organizational Behavior 31 (1): 4-23.

Goffman, Erving. 1963. Stigma: Notes on the management of spoiled identity. New York: Simon and Schuster.

Göle, Nilüfer. 2003. The voluntary adoption of Islamic stigma symbols. Social Research: An International Quarterly 70 (3): 809-28.

Gülen, M. Fethullah. 2004. The necessity of interfaith dialogue: A Muslim perspective. Clifton, NJ: The Light, Inc.

Güler, Müzeyyen. 2006. Turkish immigrants in the United States: Men, women and children. International Journal of Turkish Studies 12 (1-2): 145-65.

Hage, Ghassan. 1998. White nation: Fantasies of white supremacy in a multicultural nation. New York: Routledge.

Herek, Gregory M. (1998). Stigma and sexual orientation: Understanding prejudice against lesbians, gay men, and bisexuals. Thousand Oaks, CA: Sage. 
Herek, Gregory M., Sona Saha, and Jeffrey Burack. 2013. Stigma and psychological distress in people with HIV/AIDS. Basic and Applied Social Psychology 35 (1): 41-54.

Hewitt, Jay, and Mushubab A. Alqahtani. 2003. Differences between Saudi and U.S. students in reaction to same- and mixed-sex intimacy shown by others. The Journal of Social Psychology 143 (2): 233-42.

Howarth, Caroline. 2006. Race as stigma: Positioning the stigmatized as agents, not objects. Journal of Community and Applied Social Psychology 16 (6): 442-51.

Hutchison, Paul, Dominic Abrams, Roberto Gutierrez, and G. Tendayi Viki. 2008. Getting rid of the bad ones: The relationship between group identification, deviant derogation, and identity maintenance. Journal of Experimental Social Psychology 44 (3): 874-81.

Ibrahim, Yasmin. (2007). 9/11 as a new temporal phase for Islam: The narrative and temporal framing of Islam in crisis. Contemporary Islam 1 (1): 37-51. doi:10.1007/s11562-007-0007-x

Johns, Michael, Toni Schmader, and Brian Lickel. 2005. Ashamed to be an American? The role of identification in predicting vicarious shame for anti-Arab prejudice after 9-11. Self and Identity 4 (4): 331-48.

Kalkan, Kerem Ozan, Geoffrey C. Layman, and Erik M. Uslaner. 2009. "Bands of others"? Attitudes toward Muslims in contemporary American Society. The Journal of Politics 71 (03): 847-62.

Kaya, Ayhan. 2010. Individualization and institutionalization of Islam in Europe in the age of securitization. Insight Turkey 12 (1).

Kaya, Ilhan. 2004. Turkish-American immigration history and identity formations. Journal of Muslim Minority Affairs 24 (2): 295-308.

Kendall, Diana. 2002. The power of good deeds: Privileged women and the social reproduction of the upper class. Lanham, MD: Rowman \& Littlefield Publishers.

Khalid, Salma. (2007). Counselling from an Islamic perspective. Therapy Today, 18:34-37.

Klandermans, Bert, Jojanneke van der Toorn, and Jacquelien van Stekelenburg. 2008. Embeddedness and identity: How immigrants turn grievances into action. American Sociological Review, 73 (6): 992-1012.

Kleck, Robert. 1968. Physical stigma and nonverbal cues emitted in face-to-face interaction. Human Relations 21 (1): 19-28.

Küçükcan, Talip. 2004. The making of Turkish-Muslim diaspora in Britain: Religious collective identity in a multicultural public sphere. Journal of Muslim Minority Affairs 24 (2): 243-58.

Kurucan, Ahmet, and Mustafa Kasim Erol. 2012. Dialogue in Islam: Qur'an • Sunnah - History. London: Dialogue Society.

Lassiter, Luke Eric. 2005. Collaborative ethnography and public anthropology. Current Anthropology 46 (1): 83-106.

Leach, Colin Wayne, Patricia M. Rodriguez Mosquera, Michael L. W. Vliek, and Emily Hirt. 2010. Group devaluation and group identification. Journal of Social Issues 66 (3): 535-52. 
Lenhardt, R. A. 2004. Understanding the mark: Race, stigma, and equality in context. New York University Law Review 79:803-931.

Lentin, Alana, and Gavan Titley. 2011. The crises of multiculturalism: Racism in a neoliberal age. London: Zed Books.

Lentin, Alana, and Gavan Titley. 2012. The crisis of "multiculturalism" in Europe: Mediated minarets, intolerable subjects. European Journal of Cultural Studies 15 (2): 123-38.

Link, Bruce G., and Jo C. Phelan. 2001. Conceptualizing stigma. Annual Review of Sociology 27 (1): 363-85.

Lohmann, Roger A., and Jon Van Til, eds. 2011. Resolving community conflicts and problems: Public deliberation and sustained dialogue. Columbia University Press.

Maira, Sunaina. 2008. Belly dancing: Arab-face, Orientalist feminism, and U.S. empire. American Quarterly, 60 (2): 317-45.

Marques, José M., Vincent Y. Yzerbyt, and Jacques-Philippe Leyens. 1988. The "black sheep effect": Extremity of judgments towards ingroup members as a function of group identification. European Journal of Social Psychology 18 (1): $1-16$.

Marvasti, Amir. 2005. Being Middle Eastern American: Identity Negotiation in the Context of the War on Terror. Symbolic Interaction 28 (4): 525-47.

May, Reuben A. Buford, and Mary Patillo-McCoy. 2000. Do you see what I see? Examining a collaborative ethnography. Qualitative Inquiry 6 (1): 65-87.

Mir, Shabana. 2011. "Just to make sure people know I was born here": Muslim women constructing American selves. Discourse: Studies in the Cultural Politics of Education 32 (4): 547-63.

Nee, Victor, and Jimy Sanders. 2001. Understanding the diversity of immigrant incorporation: a forms-of-capital model. Ethnic and Racial Studies 24 (3): 386-411.

O'Brien, John. 2011. Spoiled group identities and backstage work: A theory of stigma management rehearsals. Social Psychology Quarterly 74 (3): 291-309.

Panagopoulos, Costas. 2006. The polls-trends Arab and Muslim Americans and Islam in the aftermath of 9/11. Public Opinion Quarterly 70 (4): 608-24.

Parker, Richard, and Peter Aggleton. 2003. HIV and AIDS-related stigma and discrimination: A conceptual framework and implications for action. Social Science \& Medicine 57 (1): 13-24.

Patel, Tina Girishbhai. 2012. Surveillance, suspicion and stigma: Brown bodies in a terror-panic climate. Surveillance \& Society 10 (3/4): 215-34.

Pew Research Center. 2014. Religion \& Public Life Project. Retrieved June 2014. http://www.pewforum.org/2014/09/22/section-1-religion-in-public-life/

Pfuhl, Erdwin H. 1993. The Deviance Process, third edition. New York: Aldine Transaction.

Puhl, Rebecca M., and Kelly D. Brownell. 2006. Confronting and coping with weight stigma: An investigation of overweight and obese adults. Obesity 14 (10): $1802-15$.

Rappaport, Joanne. 2008. Beyond participant observation: Collaborative ethnography as theoretical innovation. Collaborative Anthropologies 1:1-31. 
Rippy, Alyssa E., and Elana Newman. 2006. Perceived religious discrimination and its relationship to anxiety and paranoia among Muslim Americans. Journal of Muslim Mental Health 1 (1): 5-20.

Rubenstein, William B. 2004. The real story of U.S. hate crimes statistics: An empirical analysis. Tulane Law Review 78:1213-46.

Runneymede Trust. 1997. Islamophobia: A challenge for us all. London: Runnymede Trust Commission on British Muslims and Islamophobia.

Ryan, Louise. 2011. Muslim women negotiating collective stigmatization: "We're just normal people." Sociology 45 (6): 1045-60.

Said, Edward W. 1979. Orientalism, first Vintage Books edition. New York: Vintage.

Said, Edward W. 1980. Islam through Western eyes. Nation 230 (16): 488.

Saito, Natsu Taylor. 2001. Symbolism under siege: Japanese American redress and the "racing" of Arab Americans as "terrorists." Asian Law Journal 8 (1): 1-29.

Saloom, Rachel. 2005. I know you are, but what am I? Arab-American experiences through the critical race theory lens. Hamline Journal of Public Law \& Policy 27:55.

Saunders, Harold H., and Priya Narayan Parker. 2011. Sustained dialogue in action. In Resolving community conflicts and problems: Public deliberation and sustained dialogue, edited by Roger A. Lohmann and Jon Van Til. New York: Columbia University Press, 43-60.

Scambler, Graham. 2006. Sociology, social structure and health-related stigma. Psychology, Health \& Medicine, 11 (3): 288-95.

Scambler, Graham. 2009. Health-related stigma. Sociology of Health \& Illness, 31 (3): 441-55.

Senge, Peter M. 1999. The fifth discipline: The art \& practice of the learning organization. New York: Random House.

Shay, Anthony, and Barbara Sellers-Young. 2003. Belly dance: OrientalismExoticism-Self-Exoticism. Dance Research Journal 35(1).

Sirin, Selcuk R., and Aida B. Balsano. 2007. Editors' introduction: Pathways to identity and positive development among Muslim youth in the West. Applied Developmental Science 11 (3): 109-11.

Storrs, Debbie. 1999. Whiteness as stigma: Essentialist identity work by mixed-race women. Symbolic Interaction 22 (3): 187-212.

Tuastad, Dag. 2003. Neo-Orientalism and the new barbarism thesis: Aspects of symbolic violence in the Middle East conflict(s). Third World Quarterly 24 (4): 591-99.

Turam, Berna. 2004. A bargain between the secular state and Turkish Islam: Politics of ethnicity in Central Asia. Nations and Nationalism 10 (3): 353-74.

Umbreit, Mark S., Ted Lewis, and Heather Burns. 2003. A community response to a 9/11 hate crime: Restorative justice through dialogue. Contemporary Justice Review 6 (4): 383-91.

United States Census Bureau. 2010. State and Country QuickFacts. Retrieved June 2014. http://quickfacts.census.gov/qfd/index.html

Valenta, Marko. 2009. Immigrants' identity negotiations and coping with stigma in different relational frames. Symbolic Interaction, 32 (4): 351-71. 
Van Til, Jon. 2011. The structure of sustained dialogue and public deliberation. In Resolving community conflicts and problems: Public deliberation and sustained dialogue. New York: Columbia University Press, 15-32.

Wacquant, Loïc. 2010. Crafting the neoliberal state: Workfare, prisonfare, and social insecurity. Sociological Forum 25 (2): 197-220.

Yan, Grace, and Carla A. Santos. (2009). "CHINA, FOREVER": Tourism discourse and self-Orientalism. Annals of Tourism Research 36 (2): 295-315.

\section{Author Biographies}

Crystal Paul is a graduate student in Sociology at Louisiana State University. Her current research focuses on Latino immigration and the intersection of gender and race.

Sarah Becker is an assistant professor of Sociology and Women's and Gender Studies at Louisiana State University. Her primary research interests include the ethnographic study of community-based reactions to crime/disorder and the relationship between social status (gender/race/class/age) and criminal offending/victimization. 